\title{
Trichoderma viride Controls Macrophomina phaseolina through its DNA disintegration and Production of Antifungal Compounds
}

\author{
Iqra Haider Khan ${ }^{1}$, Arshad Javaid ${ }^{1 *}$ and Dildar Ahmed ${ }^{2}$ \\ ${ }^{1}$ Institute of Agricultural Sciences, University of the Punjab, Quaid-i-Azam Campus, Lahore, Pakistan \\ ${ }^{2}$ Department of Chemistry, Forman Christian College (A Chartered University), Lahore, Pakistan \\ *For correspondence: arshad.iags@pu.edu.pk; arshadjpk@yahoo.com \\ Received 16 October 2020; Accepted 16 January 2021; Published 25 March 2021
}

\begin{abstract}
Macrophomina phaseolina is a highly destructive pathogen of more than 500 plant species. It is difficult to eradicate it through chemical means as no patented fungicide is available against this pathogen. Biological control is the possible alternative method for its suitable management. The present study was carried out to evaluate the biocontrol potential of five Trichoderma spp. against $M$. phaseolina and the possible mechanisms of action. Identifications of all the Trichoderma spp. viz. T. hamatum, T. harzianum, T. koningii, T. longipile and $T$. viride were confirmed on molecular basis by using two universal primer pairs namely ITS and EF1. Their biocontrol potential was evaluated in dual culture plate method where $T$. viride showed the highest inhibitory efficacy (63\%) against $M$. phaseolina. T. koningii, T. hamatum and T. longipile showed akin effects by arresting growth of the pathogen by $46-47 \%$ followed by $T$. harzianum $(28 \%)$. To find out the mechanisms of action, secondary extrolites of the best biocontrol fungus $T$. viride were tested against the pathogenic genomic DNA where all the concentrations partially degraded DNA bands after $24 \mathrm{~h}$ of incubation and a complete DNA band disappearance was noted after $48 \mathrm{~h}$ incubation. In addition, $T$. viride culture filtrates were partitioned with chloroform and ethyl acetate and subjected to GC-MS analysis for identification of potential antifungal constituents. The most abundant identified volatile compounds in the two organic solvent fractions were 9,12-octadecadienoic acid (Z,Z)- (44.54\%), $n$-hexadecanoic acid (24.02\%), hexadecanoic acid, 2-hydroxy-1-(hydroxymethyl) ethyl ester (14.25\%), 9-tricosene, (Z)- (10.43\%) and [1,1'-bicyclopropyl]-2-octanoic acid, 2'hexyl-, methyl ester (10.43\%). To conclude, T. viride was the best biocontrol agent against M. phaseolina and acts against the pathogen by DNA disintegration and production of antifungal secondary metabolites. (C) 2021 Friends Science Publishers
\end{abstract}

Keywords: Biocontrol; DNA cleavage; GC-MS analysis; Macrophomina phaseolina; Secondary extrolites; Trichoderma viride

\section{Introduction}

The fungus Macrophomina phaseolina is a noxious pathogen that infects more than 500 host plant species belonging to about 100 families globally (Schroeder et al. 2019). The pathogen has a wide geographical distribution, and is commonly found in Europe, Africa, Asia, South and North America (Zimudzi et al. 2017). It causes stem rot, charcoal rot and root rot in major crops including cotton, sorghum, maize, sunflower, soybean, sesame, jute, green gram and common bean with severe yield losses (Khan et al. 2017; Degani et al. 2020). The pathogen rapidly propagates under high temperature and drought conditions (Muchero et al. 2011). Due to its persistent nature, it can remain viable in the form of microsclerotia as resistant structures in soil or infected plant debris for up to 3 years (Short et al. 1980; Vasebi et al. 2013). At initial stage of infection, its hyphae invade the plant cortical tissues which turn into grey-black sclerotia in infected areas (Chowdhury et al. 2014). As the disease progresses, the infected plant turns yellow and ultimately dies (Farnaz et al. 2018). As the pathogen is soilborne and has a wide host range, it is very difficult to manage it through traditional methods that have been largely based on the use of agronomic and cultural practices (Khalili et al. 2016). Chemical fungicides used to control fungal diseases are often applied in large quantities with repeated use in agricultural production, which pose drastic effects on the consumers and environment by toxins production (Chamorro et al. 2016). Therefore, high risk fungicides have increased the awareness to eliminate the use of synthetic products and encouraged the farmers to increase dependency on biocontrol agents for disease control (Zhang et al. 2018).

Biological control is a potential alternate to the synthetic chemical fungicides. It is considered to be an ecofriendly and low-cost strategy for the management of soilborne pathogens (Muller-Scharer et al. 2020). To date, a number of registered biocontrol agents are commercially available belonging to Trichoderma, Candida, Gliocladium, Coniothyrium, Streptomyces, Bacillus, Pseudomonas and Agrobacterium genera (Bayoumy et al. 2017; Deng et al.

To cite this paper: Khan IH, A Javaid, D Ahmed (2021). Trichoderma viride controls Macrophomina phaseolina through its DNA disintegration and production of antifungal compounds. Intl J Agric Biol 25:888-894 
2018; Zhao et al. 2018). Among them, the genus Trichoderma has a wide biotechnological interest and hence comprising on mycoparasitic species, particularly $T$. pseudokoningii, T. hamatum, T. harzianum, T. koningii and $T$. viride that have received a great attention in reducing the populations of soil-borne pathogens including Sclerotium rolfsii, Rhizoctonia solani, Fusarium oxysporum and $M$. phaseolina (Bastakoti et al. 2017). The antagonistic mechanism of Trichoderma species is a combination of diverse mechanisms including direct confrontation with fungal pathogens, competition for nutrients and the production of cell-wall degrading enzymes (Anjum et al. 2019). So far, Trichoderma spp. are the most studied biocontrol agents and are commercially marketed as biofertilizers, biopesticides and for soil amendments (Kumar et al. 2017). These serve as important antibiotic, fast growing, strong spore producer, secondary opportunistic invaders and a source of chitinases, glucanases and cellulases cell wall degrading enzymes (Hewavitharana et al. 2018). Secondary metabolites produced by Trichoderma spp. are antifungal strain dependent substances belonging to different classes of volatile compounds (Pascale et al. 2017). The direct application of anti-microbial compounds of antagonistic fungi instead of living organisms is more advantageous in agriculture and industry because of their inability to reproduce and spread (Soesanto et al. 2019). Therefore, the objective of the present study was to assess the comparative antagonistic effect of five Trichoderma species against $M$. phaseolina, and to investigate the antagonism mechanism as well as to identify the secondary extrolites produced by $T$. viride.

\section{Materials and Methods}

\section{Molecular characterization of selected isolates}

Five Trichoderma species viz. T. hamatum, T. harzianum, T. koningii, $T$. longipile and $T$. viride were procured from the First Culture Bank of Pakistan (FCBP). Genomic DNA of all the selected fungi were extracted by using CTAB method (Doyle and Doyle 1990). For molecular identification, the contiguous Internal Transcribed Spacer (ITS) and elongation factor 1-alpha (EF1) regions were amplified with primer sets given in Table 1. ITS and EF1 amplicons were loaded to electrophoresis on $1 \%$ agarose gel, purified and sequenced at the Molecular and Cellular Imaging Center (MCIC) of the Ohio Agricultural Research and Development Center, Wooster, OH, USA on the Illumina MiSeq platform. The obtained sequences were subjected to BLAST analysis and deposited in NCBI.

\section{In vitro antagonistic activity of Trichoderma species}

Dual culture experiments were conducted to determine the in vitro biocontrol potential of Trichoderma spp. against $M$. phaseolina where both the species were inoculated on peripheries of the same $90-\mathrm{mm}$ diameter malt extract agar plates. Mycelial agar plugs (5 $\mathrm{mm}$ in diameter) of each filamentous Trichoderma culture were placed at opposite end of the tested pathogen ( $5 \mathrm{~mm}$ in diameter) for the establishment of dual culture and a control was also prepared by placing $M$. phaseolina plugs only. Each treatment contained six replicates and the plates were incubated at $28^{\circ} \mathrm{C}$ for 5 days. The experiment was carried out in a completely randomized design. The antagonistic potential of each Trichoderma species was assessed by measuring the pathogen radial growth in the direction of Trichoderma isolates and calculated by using the following formula (Rini and Sulochana 2008):

$$
\text { Inhibition }(\%)=\frac{\text { Colony diameter in control }- \text { Colony diameter in dual culture }}{\text { Colony diameter in control }} \times 100
$$

\section{DNA degradation study}

T. viride secondary metabolites were used to explore their potential antagonistic mechanism against $M$. phaseolina in a DNA degradation experiment. For the preparation of secondary metabolites, mycelial agar plugs $(5 \mathrm{~mm}$ in diameter) of $T$. viride were inoculated in malt extract broth flasks which were agitated for two weeks on an orbital shaker $(150 \mathrm{rpm})$ at $30^{\circ} \mathrm{C}$. Subsequently, the broth was passed through two layers of filter paper and the resultant liquid was kept in an electric oven at $40^{\circ} \mathrm{C}$ to concentrate it for the preparation of higher concentrations viz. 100, 200, 300,400 and $500 \%$. Next, $5 \mu \mathrm{L}$ of each concentration were mixed in equal volume of $M$. phaseolina DNA in separate vials and incubated at $37^{\circ} \mathrm{C}$ for 24 and $48 \mathrm{~h}$. A control was also set for comparison. Thereafter, all the treatments were loaded on $1 \%$ agarose gel and run for $45 \mathrm{~min}$ at 100 volts to examine the extent of DNA degradation (Katrahalli et al. 2019).

\section{GC-MS analysis}

Mycelial discs were taken from the margins of an actively growing culture of $T$. viride and inoculated in $100 \mathrm{~mL}$ autoclaved malt extract broth in Erlenmeyer flasks $(250 \mathrm{~mL})$ under aseptic conditions. Inoculated flasks were agitated on an orbital shaker $(150 \mathrm{rpm})$ at $30^{\circ} \mathrm{C}$ for 15 days. The broth was filtered through Whatman filter paper to remove mycelia. The broth was then partitioned with chloroform followed by ethyl acetate in a glass separating funnel. The obtained fractions were subjected to GC-MS analysis for identification of compounds.

Analysis was done on GC-2010 plus, Shimadzu attached with DB-5MS. The capillary column was $0.25 \mu \mathrm{m}$ $\times 0.25 \mathrm{~mm} \times 30 \mathrm{~m}$ with temperature capacity of $350^{\circ} \mathrm{C}$. A mass spectral library, Version 2.70, Shimadzu Co., was used. Helium as a carrier gas was used in pure form in accordance with split-less injection system $(1.0 \mu \mathrm{L}$ volume $)$, developed for operating the chromatograph with $1 \mathrm{~cm}^{3} \mathrm{~min}^{-1}$ spill count at $250^{\circ} \mathrm{C}$. The total sample running time was set for $11 \mathrm{~min}$. 


\section{Statistical analysis}

The dual culture experiment was conducted in a completely randomized design with six replicates. For each treatment, standard errors of the means were calculated. Data regarding percentage inhibition in growth of $M$. phaseolina due to various Trichoderma spp. in dual culture plates were analyzed statistically by applying one-way ANOVA followed by LSD test at $\mathrm{P} \leq 0.05$, using computer software Statistix 8.1.

\section{Results}

\section{Molecular identification of antagonistic fungi}

In the present study, molecular characterization of $T$. hamatum, T. harzianum, T. koningii, T. longipile and $T$. viride rDNA was carried out with ITS and EF1 universally accepted primers (Fig. 1). The resultant PCR product sequences were subjected to BLAST analysis where all the isolated strains showed 99 to $100 \%$ similarities with the already submitted sequences and deposited to Genebank for respective accession numbers (Table 2).

\section{Interactions of Trichoderma spp. with $M$. phaseolina}

Among the five tested Trichoderma spp., T. viride showed the best antagonistic potential against $M$. phaseolina by arresting its growth up to $64 \%$ over control. Rest of the Trichoderma species were less effective than $T$. viride where about akin reduction $(46-47 \%)$ in the pathogen growth was observed due to $T$. koningii, T. hamatum and $T$. longipile. T. harzianum showed the least suppressive ability and reduced growth of the pathogen only by $28 \%$ (Fig. 2 $3)$.

\section{DNA degradation study}

Interaction of $M$. phaseolina ribosomal DNA with secondary metabolites of $T$. viride is illustrated in Fig. 4. All the concentrations except $500 \%$ partially cleaved the pathogenic fungus DNA and form smears after $24 \mathrm{~h}$ of incubation whereas the $500 \%$ concentration was found to be more effective than lower concentrations and completely disintegrated DNA of the fungal pathogen. After $48 \mathrm{~h}$ of incubation, it was noted that all the concentrations completely damaged $M$. phaseolina DNA.

\section{GC-MS analysis}

The GC-MS chromatogram of $T$. viride chloroform and ethyl acetate fractions showed the presence of 4 and 9 peaks of volatile compounds, respectively (Fig. 5). The compounds in chloroform fraction with their details of percent peak areas and retention time are reported in Table 3. The compound present in the highest concentration was
Table 1: List of oligonucleotide primers used for the characterization of $T$. viride at molecular level

\begin{tabular}{lll}
\hline Primer name & $5^{\prime}$ to $3^{\prime}$ sequence & $\begin{array}{l}\text { Annealing } \\
\text { temperature }\end{array}$ \\
\hline ITS 1 Forward & TCCGTAGGTGAACCTGCGG & $60^{\circ} \mathrm{C}$ \\
ITS 4 Reverse & TCCTCCGCTTATTGATATGC & \\
EF1-728 Forward & CATCGAGAAGTTCGAGAAGG $60^{\circ} \mathrm{C}$ \\
EF1-986 Reverse & TACTTGAAGGAACCTTACC & \\
\hline
\end{tabular}

Table 2: Trichoderma spp. with their respective accession numbers and products amplicon size

\begin{tabular}{lllll}
\hline $\begin{array}{l}\text { Penicillium } \\
\text { spp. }\end{array}$ & \multicolumn{3}{c}{ ITS } & \multicolumn{2}{c}{ EF-1 } \\
\cline { 2 - 5 } & $\begin{array}{l}\text { Amplicon } \\
\text { (bp) }\end{array}$ & $\begin{array}{c}\text { size Accession } \\
\text { numbers }\end{array}$ & $\begin{array}{l}\text { Amplicon } \\
(\mathrm{bp})\end{array}$ & $\begin{array}{l}\text { size } \\
\text { Accession } \\
\text { numbers }\end{array}$ \\
\hline T. hamatum & $\sim 535$ & MT573507 & $\sim 354$ & MN736405 \\
T. harzianum & $\sim 556$ & MN721820 & $\sim 333$ & MN736406 \\
T. koningii & $\sim 538$ & MT573514 & $\sim 363$ & MN736407 \\
T. longipile & $\sim 547$ & MT573512 & $\sim 435$ & MN736408 \\
T. viride & $\sim 554$ & MT573511 & $\sim 368$ & MN736410 \\
\hline
\end{tabular}

Table 3: Compounds identified from chloroform fraction of culture filtrates of $T$. viride through GC-MS analysis

\begin{tabular}{|c|c|c|c|c|}
\hline Names of compounds & $\begin{array}{l}\text { Molecular } \\
\text { formula }\end{array}$ & $\begin{array}{l}\text { Molecular } \\
\text { weight }\end{array}$ & $\begin{array}{l}\text { Retention } \\
\text { time (min) }\end{array}$ & $\begin{array}{l}\text { Peak } \\
\text { area }(\%)\end{array}$ \\
\hline n-Hexadecanoic acid & $\mathrm{C}_{16} \mathrm{H}_{32} \mathrm{O}_{2}$ & 256 & 7.067 & 24.02 \\
\hline 9,12-Octadecadienoic acid (Z,Z)- & $\mathrm{C}_{18} \mathrm{H}_{32} \mathrm{O}_{2}$ & 280 & 7.809 & 44.54 \\
\hline $\begin{array}{l}\text { [1,1'-Bicyclopropyl]-2-octanoic } \\
\text { acid, 2'-hexyl-,methyl ester }\end{array}$ & $\mathrm{C}_{21} \mathrm{H}_{38} \mathrm{O}_{2}$ & 322 & 9.197 & 10.43 \\
\hline $\begin{array}{l}\text { Octadecanoic acid, } \\
\text { dihydroxy-, methyl ester }\end{array}$ & $\mathrm{C}_{19} \mathrm{H}_{38} \mathrm{O}_{4}$ & 330 & 9.415 & 20.89 \\
\hline
\end{tabular}

Table 4: Compounds identified from ethyl acetate fraction of culture filtrate of $T$. viride through GC-MS analysis

\begin{tabular}{lllll}
\hline Names of compounds & $\begin{array}{l}\text { Molecula } \\
\mathrm{r} \text { formula }\end{array}$ & $\begin{array}{l}\text { Molecular } \\
\text { weight }\end{array}$ & $\begin{array}{l}\text { Retention } \\
\text { time (min) }\end{array}$ & $\begin{array}{l}\text { Peak area } \\
(\%)\end{array}$ \\
\hline Benzene, nitro- & $\mathrm{C}_{6} \mathrm{H}_{5} \mathrm{NO}_{2}$ & 123 & 2.857 & 15.05 \\
Naphthalene & $\mathrm{C}_{10} \mathrm{H}_{8}$ & 128 & 3.395 & 4.99 \\
n-Hexadecanoic acid & $\mathrm{C}_{16} \mathrm{H}_{32} \mathrm{O}_{2}$ & 256 & 7.073 & 6.55 \\
1-Nonadecene & $\mathrm{C}_{19} \mathrm{H}_{38}$ & 266 & 7.203 & 5.70 \\
9,12-Octadecadienoic acid (Z,Z)- & $\mathrm{C}_{18} \mathrm{H}_{32} \mathrm{O}_{2}$ & 280 & 7.796 & 40.09 \\
9-Tricosene, (Z)- & $\mathrm{C}_{23} \mathrm{H}_{46}$ & 322 & 8.015 & 10.43 \\
$\begin{array}{l}\text { Cis-9-Hexadecenal } \\
\text { Hexadecanoic acid,2-hydroxy-1- } \\
\text { (hydroxymethyl) ethyl ester }\end{array}$ & $\mathrm{C}_{16} \mathrm{C}_{30} \mathrm{H}_{38} \mathrm{O}_{4}$ & 238 & 8.621 & 2.84 \\
3- $n$-Butylthiophene-1,1-dioxide & $\mathrm{C}_{8} \mathrm{H}_{12} \mathrm{O}_{2} \mathrm{~S}$ & 172 & 9.628 & 14.25 \\
\hline
\end{tabular}

9,12-octadecadienoic acid (Z,Z)- (44.54\%). The moderately abundant compounds in this fraction were $n$-hexadecanoic acid $(24.02 \%)$, octadecanoic acid, 9,10-dihydroxy-, methyl ester $(20.89 \%)$ and [1,1'-bicyclopropyl]-2-octanoic acid, 2'hexyl-, methyl ester (10.43\%).

Details of ethyl acetate fraction spectrum profile are given in Table 4. Ethyl acetate fraction showed the highest abundunce of 9,12-octadecadienoic acid (Z,Z)- (40.09\%) whereas, the compounds present in moderate concentrations were benzene, nitro- (15.05\%), hexadecanoic acid, 2-hydroxy1-(hydroxymethyl) ethyl ester (14.25\%) and 9-tricosene, (Z)$(10.43 \%)$. On the other hand, $n$-hexadecanoic acid $(6.55 \%)$, 1-nonadecene (5.70\%), naphthalene (4.99\%), 3-nbutylthiophene-1,1-dioxide $(4.20 \%)$ and cis-9-hexadecenal $(2.84 \%)$ were ranked as less abundant compounds. 


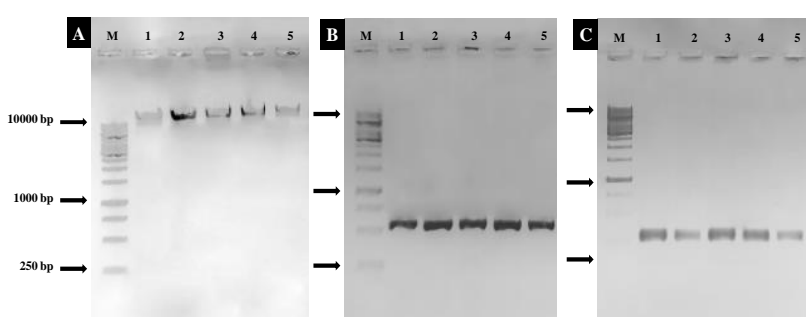

Fig. 1: Molecular characterization of Trichoderma species A)- Genomic DNA of Trichoderma species. B)- ITS1/ITS4 amplified PCR product of Trichoderma species. C)- $\mathrm{EF}_{\mathrm{f}} / \mathrm{EF}_{\mathrm{r}}$ amplified PCR product of Trichoderma species (M): 1 kb DNA standard marker, (1): T. hamatum, (2): T. harzianum, (3): T. koningii, (4): T. longipile, (5): T. viride
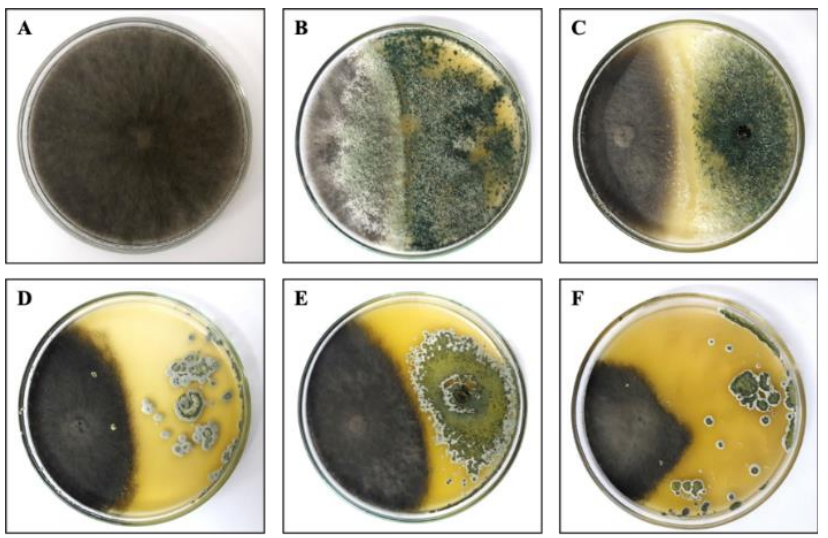

Fig. 2: Interaction of $M$. phaseolina with Trichoderma species A)- Pure culture of M. phaseolina (MP); B)- MP co-culture with T. viride; C)- MP coculture with T. hamatum; D)- MP co-culture with T. longipile; E)- MP co-culture with T. harzianum; and F)- MP co-culture with T. koningii

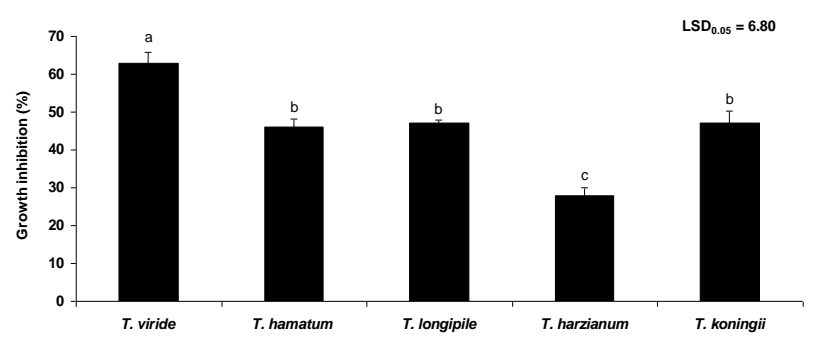

Fig. 3: Inhibition in radial growth of $M$. phaseolina due to interaction with different Trichoderma species Vertical bars show standard errors of means of six replicates. Values with different letters at their top show significant difference $(P \leq 0.05)$ as determined by LSD test

\section{Discussion}

Accurate identification of Trichoderma spp. is necessary to study their detailed mechanism of antagonism and for the preparation of effective management strategies against the soil-borne fungal pathogens (Mokhtari et al. 2017). Genomic DNA sequence and amplification through universal set of primer pairs is the most authentic tool for identification on molecular basis (Sawant et al. 2019). In the present investigation, Trichoderma spp., especially $T$. viride,
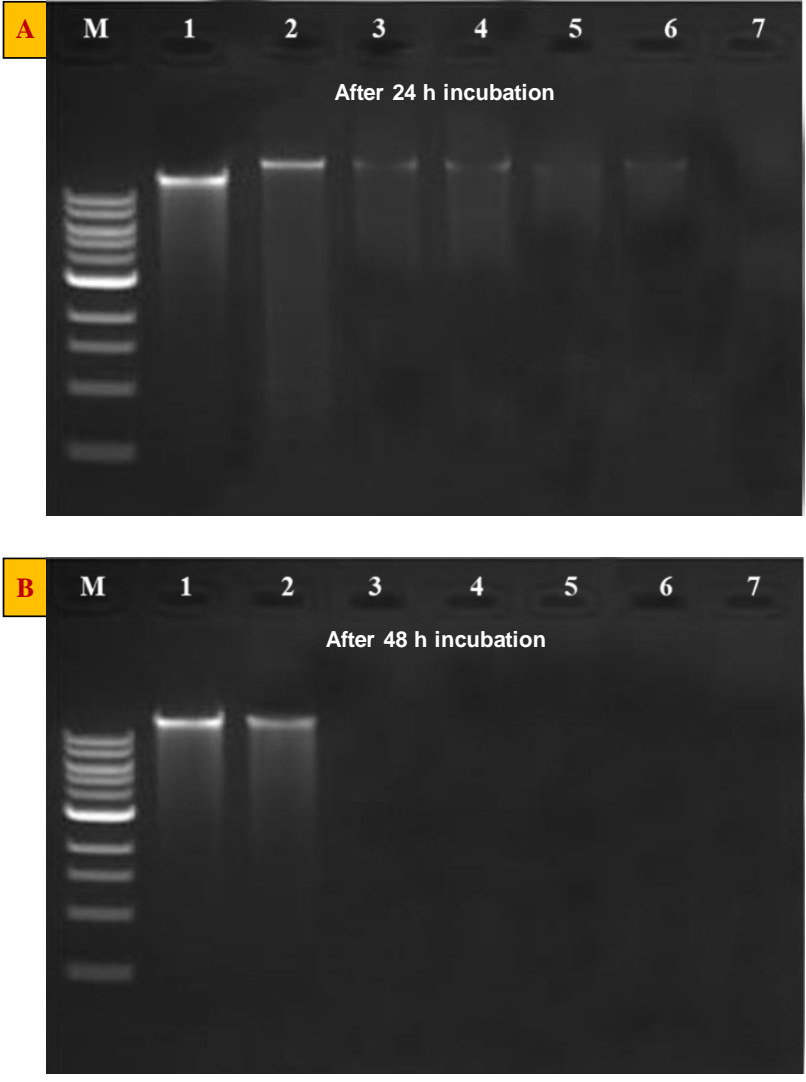

Fig. 4: Gel electrophoresis showing effect of different concentrations of secondary metabolites of $T$. viride on cleavage of M. phaseolina DNA samples incubated for $24 \mathrm{~h}$ (A) and $48 \mathrm{~h}$ (B) (M): $1 \mathrm{~kb}$ DNA standard marker, (1): Genomic DNA of M. phaseolina, (2): Negative control (genomic DNA of M. phaseolina + malt extract broth), (3): original or 100\% metabolites, (4): $200 \%$ metabolites, (5): 300\% metabolites, (6): $400 \%$ metabolites, and (7): 500\% metabolites. Arrows indicate the presence or absence of DNA

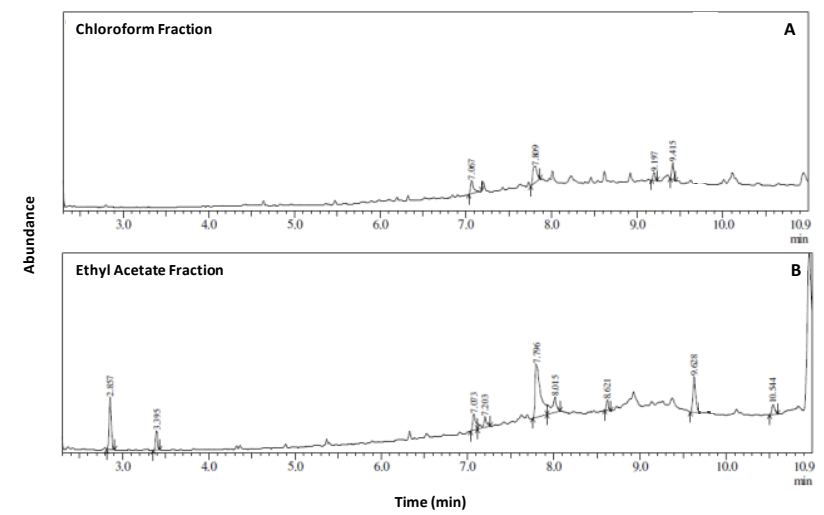

Fig. 5: GC-MS chromatograms of chloroform and ethyl acetate fractions of culture filtrate of $T$. viride

remarkably inhibited the growth of $M$. phaseolina. Previously, Gaur (2016) worked on T. atroviride, T. viride and $T$. harzianum under in vitro conditions to assess their antagonistic potential towards the $M$. phaseolina by direct co-culturing on Czapek's dox medium where all the isolates showed promising inhibitory effects on growth of the 
Khan et al. / Intl J Agric Biol, Vol 25, No 4, 2021

Table 5: Potential antimicrobial constituents in chloroform and ethyl acetate fraction of $T$. viride

\begin{tabular}{|c|c|c|}
\hline Names of compounds & Property & Reference \\
\hline 9,12-Octadecadienoic acid (Z,Z)- & $\begin{array}{l}\text { Antifugal, antibacterial, nematicidal, } \\
\text { anti-coronary and anti-inflammatory }\end{array}$ & $\begin{array}{l}\text { Tahir et al. (2019); Arora and Kumar (2018); Prajapati et } \\
\text { al. (2017) }\end{array}$ \\
\hline$n$-Hexadecanoic acid & $\begin{array}{l}\text { Antifungal, nematicide, pesticide } \\
\text { and antioxidant }\end{array}$ & $\begin{array}{l}\text { Pavithra et al. (2018); Vats and Gupta (2017); Elaiyaraja } \\
\text { and Chandramohan (2016); Pohl et al. (2011) }\end{array}$ \\
\hline $\begin{array}{l}\text { Hexadecanoic acid,2-hydroxy-1-(hydroxymethyl) ethyl } \\
\text { ester }\end{array}$ & $\begin{array}{l}\text { Antibacterial, anti-inflammatory and } \\
\text { antioxidant }\end{array}$ & Al-Marzoqi et al. (2015); Pandey et al. (2014) \\
\hline 9-Tricosene, (Z)- & Pesticidal & Verma et al. (2015) \\
\hline [1,1'-Bicyclopropyl]-2-octanoic acid,2'-hexyl-,methyl ester & Pesticide, antican & Banakar and Jayaraj (2017) \\
\hline 1-Nonadecene & Antifungal and Anticancer & Premathilaka and Silva (2016) \\
\hline Naphthalene & Antioxidant and antibacterial & Shareef et al. (2016) \\
\hline cis-9-Hexadecenal & Antimicrobial & Juliet et al. (2018); Arora and Meena (2017) \\
\hline
\end{tabular}

pathogen. Similarly, a clear inhibition zone formation was observed against $M$. phaseolina by $T$. viride in dual culture assay performed by Piperkova et al. (2016). Likewise, Mishra and Dantre (2017) treated soybean seeds with secondary metabolite formulations of $T$. viride to manage the charcoal rot disease caused by $M$. phaseolina under field conditions. Trichoderma spp. are known to have a number of mechanisms through which these control the growth of pathogenic fungi. Trichoderma spp. may control the growth of pathogenic fungi through mycoparasitism (Mukhopadhyay and Kumar 2020). A complex system of various extracellular enzymes such as chitinase (Hoell et al. 2005), proteolytic enzymes (Pozo et al. 2004) and $\beta-1,3-$ glucanolytic system (Kubicek et al. 2001), results in lysis of cell wall of the fungal pathogens (Verma et al. 2007). In addition, Trichoderma spp. also inhibit hyphal growth of the fungal pathogens through antibiosis by producing antimicrobial compounds in the culture (Gajera et al. 2020).

Considering the significant antifungal activity of $T$. viride in dual culture assay, its extrolites were selected for evaluation of their effect on in vitro degradation of DNA of the pathogenic fungus. In this study, secondary extrolites showed great potential in degrading the genomic DNA after $48 \mathrm{~h}$ incubation. Earlier, this mechanism of action of $T$. viride against fungal pathogens has not been reported. Instead, generally this methodology was adopted to assess the antibacterial mechanism of action of nanoparticles (Dong et al. 2017; Dashamiri et al. 2018; Jadhav et al. 2018). A variety of lytic enzymes and antifungal compounds are produced by $T$. viride, which might be responsible of DNA degradation in the present study (Calistru et al. 1997; Parizi et al. 2012).

The GC-MS analysis showed many compounds from chloroform and ethyl acetate fractions that were previously reported to have antimicrobial properties. Among the major identified constituents, 9,12-octadecadienoic acid (Z,Z)was previously isolated from the methanolic extract of Cenchrus biflorus with potent antibacterial, nematicidal and fungicidal activities as given in Table 5 (Arora and Kumar 2018; Tahir et al. 2019). Similarly, Pavithra et al. (2018) worked on bioactivity of $n$-hexadecanoic acid (also known as palmitic acid) and reported that it possesses strong pesticidal and antioxidant properties. This compound is known to exhibit antifungal activity against a number of fungal species including Aspergillus terreus, A. niger, A. nidulans (Emericella nidulans) Alernaria solani, Fusarium oxysporum and Cucumerinum lagenarium (Pohl et al. 2011). Likewise, hexadecanoic acid,2-hydroxy-1(hydroxymethyl) ethyl ester was isolated from the methanolic extract of Limonia acidissima and tested against pathogenic bacterial strains. The compound showed excellent antibacterial potential against $S$. aureus, $S$. epidermidis and B. subtilis (Pandey et al. 2014). Verma et al. (2015) reported pesticidal potential of 9-tricosene, (Z)and [1,1'-bicyclopropyl]-2-octanoic acid, 2'-hexyl-, methyl ester. Similarly, 1-nonadecene; naphthalene and cis-9hexadecenal are potent antifungal and antioxidant compounds (Premathilaka and Silva 2016; Shareef et al. 2016; Juliet et al. 2018).

\section{Conclusion}

There was antagonistic potential of $T$. viride against a highly problematic fungal pathogen $M$. phaseolina. $T$. viride possibly controlled the pathogen by degrading its DNA through its secondary metabolites released in the surroundings. Moreover, the GC-MS analysis of secondary metabolites showed the presence of compounds such as 9,12-octadecadienoic acid (Z,Z)- and $n$-hexadecanoic acid, which are known for their antifungal effects.

\section{Author Contributions}

IHK did experimental work and wrote the paper. AJ supervised the work and contributed in writing and finalizing the paper. DA provided GC-MS facility.

\section{Conflict of Interest}

There is no conflict of interest among the authors and institutions where the work has been done

\section{Data Availability Declaration}

All data reported in this article are available with the corresponding authors and can be produced on demand 


\section{References}

Al-Marzoqi AH, IH Hameed, SA Idan (2015). Analysis of bioactive chemical components of two medicinal plants (Coriandrum sativum and Melia azedarach) leaves using gas chromatography-mass spectrometry (GC-MS). Afr J Biotechnol 14:2812-2830

Anjum R, M Afzal, R Baber, MAJ Khan, W Kanwal, W Sajid, A Raheel (2019). Endophytes: As potential biocontrol agent-review and future prospects. J Agric Sci 11:113-125

Arora S, S Meena (2017). GC-MS profiling of Ceropegia bulbosa Roxb. var. bulbosa, an endangered plant from thar desert, Rajasthan. Pharma Innov 6:568-573

Arora S, G Kumar (2018). Phytochemical screening of root, stem and leaves of Cenchrus biflorus Roxb. J Pharm Phytochem 7:1445-1450

Banakar P, M Jayaraj (2017). Pharmacognosy, phytochemistry and GC-MS analysis of ethanolic stem extract of Waltheria indica L.-A potent medicinal plant. J Biol Prod Nat 7:369-378

Bastakoti S, S Belbase, S Manandhar, C Arjyal (2017). Trichoderma species as biocontrol agent against soil borne fungal pathogens. Nep J Biotechnol 5:39-45

Bayoumy S, A Afify, A El-Sayed, S Elshal (2017). Antagonistic effect of Bacillus spp. against sugar beet pathogens fusarium wilt. J Agric Chem Biotechnol 8:177-181

Calistru C, M McLean, P Berjak (1997). In vitro studies on the potential for biological control of Aspergillus flavus and Fusarium moniliforme by Trichoderma species. A study of the production of extracellular metabolites by Trichoderma species. Mycopathologia 137:115-124

Chamorro M, TE Seijo, JC Noling, B De los Santos, NA Peres (2016). Efficacy of fumigant treatments and inoculum placement on control of Macrophomina phaseolina in strawberry beds. Crop Prot 90:163-169

Chowdhury S, A Basu, TR Chaudhuri, S Kundu (2014). In-vitro characterization of the behavior of Macrophomina phaseolina (Tassi) Goid at the rhizosphere and during early infection of roots of resistant and susceptible varieties of sesame. Eur J Plant Pathol 138:361-375

Dashamiri S, M Ghaedi, A Salehi, R Jannesar (2018). Antibacterial, antifungal and E. coli DNA cleavage of Euphorbia prostrata and Pelargonium graveolens extract and their combination with novel nanoparticles. Braz J Pharm Sci 54; Article e177724

Degani O, S Dor, D Abraham, R Cohen (2020). Interactions between Magnaporthiopsis maydis and Macrophomina phaseolina, the causes of wilt diseases in maize and cotton. Microorganisms 8; Article 249

Deng JJ, WQ Huang, ZW Li, DL Lu, Y Zhang, XC Luo (2018). Biocontrol activity of recombinant aspartic protease from Trichoderma harzianum against pathogenic fungi. Enzyme Microb Technol 112:35-42

Dong ZY, N Rao, M Prabhu, M Xiao, HF Wang, WN Hozzein, WJ Li (2017). Antibacterial activity of silver nanoparticles against Staphylococcus warneri synthesized using endophytic bacteria by photo-irradiation. Front Microbiol 8; Article 1090

Doyle JJ, JL Doyle (1990). Isolation of plant DNA from fresh tissue. Focus $12: 39-40$

Elaiyaraja A, G Chandramohan (2016). Comparative phytochemical profile of Indoneesiella echioides (L.) nees leaves using GC-MS. J Pharm Phytochem 5:158-171

Farnaz AA, A Narmani, M Arzanlou (2018). Macrophomina phaseolina associated with grapevine decline in Iran. Phytopathol Mediterr 57:107-111

Gajera HP, DG Hirpara, DD Savaliya, BA Golakiya (2020). Extracellular metabolomics of Trichoderma biocontroller for antifungal action to restrain Rhizoctonia solani Kuhn in cotton. Physiol Mol Plant Pathol 112; Article 101547

Gaur VK (2016). Study of the isolation and antagonistic effect of microorganism viz., Trichoderma and Bacillus spp. against different isolates of Macrophomina phaseolina [Tassi] Goid. in vitro. Ann Agric Biol Res 21:144-148

Hewavitharana N, SDP Kannangara, SP Senanayake (2018). Isolation, identification and mass production of five Trichoderma spp. on solid and liquid carrier media for commercialization. Intl J Appl Sci Biotechnol 6:285-293
Hoell IA, SS Klemsdal, G Vaaje-Kolstad, SJ Horn, VGH Eijsink (2005). Overexpression and characterization of a novel chitinase from Trichoderma atroviride strain P1. Biochim Biophys Acta 1748:180-190

Jadhav MS, S Kulkarni, P Raikar, DA Barretto, SK Vootla, US Raikar (2018). Green biosynthesis of $\mathrm{CuO} \& \mathrm{Ag}-\mathrm{CuO}$ nanoparticles from Malus domestica leaf extract and evaluation of antibacterial, antioxidant and DNA cleavage activities. J Chem 42:204-213

Juliet YS, K Kalimuthu, C Vajjiram, V Ranjitha (2018). Evaluation and comparison of phytochemical, GCMS and FTIR analysis of wild and micro propagated Cadaba fruticosa (L.). World $J$ Pharm Res 7:746-760

Katrahalli U, BC Yallur, DH Manjunatha, PM Krishna (2019). BSA interaction and DNA cleavage studies of anti-bacterial benzothiazol2-yl-malonaldehyde. J Mol Str 1196:96-104

Khalili E, MA Javed, F Huyop, S Rayatpanah, S Jamshidi, RA Wahab (2016). Evaluation of Trichoderma isolates as potential biological control agent against soybean charcoal rot disease caused by Macrophomina phaseolina. Biotechnol Biotechnol Equip 30:479-488

Khan AN, F Shair, K Malik, Z Hayat, MA Khan, FY Hafeez, MN Hassan (2017). Molecular identification and genetic characterization of Macrophomina phaseolina strains causing pathogenicity on sunflower and chickpea. Front Microbiol 8; Article 1309

Kubicek CP, RL Mach, CK Peterbauer, M Lorito (2001). Trichoderma: From genes to biocontrol. J Plant Pathol 83:11-23

Kumar G, A Maharshi, J Patel, A Mukherjee, HB Singh, BK Sarma (2017). Trichoderma: A potential fungal antagonist to control plant diseases. SATSA Mukhapatra Ann Tech Issue 21:206-218

Mukhopadhyay R, D Kumar (2020). Trichoderma: A beneficial antifungal agent and insights into its mechanism of biocontrol potential. Egypt $J$ Biol Pest Cont 30; Article 133

Mishra PK, RK Dantre (2017). Evaluation of different biological agents used as seed treatment to manage charcoal rot of soybean. Biosci Trend 10:2784-2788

Mokhtari W, N Chtaina, E Halmschlager, H Volgmayr, C Stauffer, W Jaklitsch (2017). Potential antagonism of some Trichoderma strains isolated from Moroccan soil against three phytopathogenic fungi of great economic importance. Rev Maroc Sci Agron Vet 5:248-254

Muchero W, JD Ehlers, TJ Close, PA Roberts (2011). Genic SNP markers and legume synteny reveal candidate genes underlying QTL for Macrophomina phaseolina resistance and maturity in cowpea [Vigna unguiculata (L) Walp.]. BMC Genomics 12; Article 8

Muller-Scharer H, S Bouchemousse, M Litto, PB McEvoy, GK Roderick, Y Sun (2020). How to better predict long-term benefits and risks in weed biocontrol: An evolutionary perspective. Curr Opin Insect Sci 38:84-91

Pandey S, G Satpathy, RK Gupta (2014). Evaluation of nutritional, phytochemical, antioxidant and antibacterial activity of exotic fruit Limonia acidissima. J Pharm Phytochem 3:81-88

Pascale A, F Vinale, G Manganiello, M Nigro, S Lanzuise, M Ruocco, M Lorito (2017). Trichoderma and its secondary metabolites improve yield and quality of grapes. Crop Prot 92:176-181

Pavithra KS, J Annadurai, R Ragunathan (2018). Phytochemical, antioxidant and a study of bioactive compounds from Artemisia pallens. J Pharm Phytochem 7:664-675

Parizi TZ, M Ansari, T Elaminejad (2012). Evaluation of the potential of Trichoderma viride in the control of fungal pathogens of Roselle (Hibiscus sabdariffa L.) in vitro. Microb Pathol 52:201-205

Piperkova N, M Zarkova, B Ahmed (2016). Characterization of Macrophomina phaseolina and Fusarium spp. isolates from sunflower. Agric Sci 8:95-100

Pohl CH, JLF Kock, VS Thibane (2011). Antifungal free fatty acids: A review. In: Science against Microbial Pathogens: Communicating Current Research and Technological Advances, pp:61-71. MéndezVilas A (Ed.). Formatex Research Center, Norristown, Philadelphia, USA

Pozo MJ, JM Baek, JM Garcia, CM Kenerley (2004). Functional analysis of tvsp1, a serine protease-encoding gene in the biocontrol agent Trichoderma virens, Fungal Genet Biol 41:336-348 
Prajapati R, LK Thakur, U Singh (2017). Melia azedarach seed oil EC formulation and evaluation of its antifungal activity against Rhizoctonia solani and Sclerotium rolfsii pathogens. Adv Bioresour 8:141-147

Premathilaka ULRR, GMSW Silva (2016). Bioactive compounds and antioxidant activity of Bunchosia armeniaca. World J Pharm Pharm Sci 5:1237-1247

Rini CR, KK Sulochana (2008). Usefulness of Trichoderma and Pseudomonas against Rhizoctonia solani and Fusarium oxysporum infecting tomato. J Trop Agric 45:21-28

Sawant AM, R Vankudoth, V Navale, R Kumavat, P Kumari, B Santhakumari, KR Vamkudoth (2019). Morphological and molecular characterization of Penicillium rubens isolated from poultry feed. Ind Phytopathol 72:461-478

Schroeder MM, Y Lai, M Shirai, N Alsalek, T Tsuchiya, P Roberts, T Eulgem (2019). A novel Arabidopsis pathosystem reveals cooperation of multiple hormonal response-pathways in host resistance against the global crop destroyer Macrophomina phaseolina. Sci Rep 9; Article 20083

Shareef HK, HJ Muhammed, HM Hussein, IH Hameed (2016). Antibacterial effect of ginger (Zingiber officinale) roscoe and bioactive chemical analysis using gas chromatography mass spectrum. Orient J Chem 32:20-40

Short GE, TD Wyllie, PR Bristow (1980). Survival of Macrophomina phaseolinain soil and in residue of soybean. Phytopathology 70:13-17

Soesanto L, E Mugiastuti, A Manan (2019). Raw secondary metabolites application of two Trichoderma harzianum isolates towards vascular streak dieback on cocoa seedlings. Pelita Perk 35:22-32
Tahir NA, HA Azeez, HH Hama-Amin, JS Rashid, DA Omer (2019). Antibacterial activity and allelopathic effects of extracts from leaf, stem and bark of Mt. Atlas mastic tree (Pistacia atlantica subsp kurdica) on crops and weeds. Allelopathy J 46:121-32

Vasebi Y, N Safaie, A Alizadeh (2013). Biological control of soybean charcoal root rot disease using bacterial and fungal antagonists in vitro and greenhouse condition. J Crop Prot 2:139-150

Vats S, T Gupta (2017). Evaluation of bioactive compounds and antioxidant potential of hydroethanolic extract of Moringa oleifera Lam. from Rajasthan, India. Physiol Mol Biol Plant 23:239-248

Verma M, SK Brar, RD Tyagi, RY Surampalli, JR Valero (2007). Antagonistic fungi, Trichoderma spp.: Panoply of biological control. Biochem Eng J 37:1-20

Verma VP, SH Kumar, KV Rani, N Sehgal, O Prakash (2015). Compound profiling in methanol extract of Kalanchoe blossfeldiana (flaming katy) leaves through GC-MS analysis and evaluation of its bioactive properties. Glob J Adv Biol Sci 1:38-49

Zhang S, B Xu, J Zhang, Y Gan (2018). Identification of the antifungal activity of Trichoderma longibrachiatum T6 and assessment of bioactive substances in controlling phytopathogen. Pestic Biochem Physiol 147:59-66

Zhao L, Y Xu, X Lai (2018). Antagonistic endophytic bacteria associated with nodules of soybean (Glycine max L.) and plant growthpromoting properties. Braz J Microbiol 49:269-278

Zimudzi J, TA Coutinho, JE Van der Waals (2017). Pathogenicity of fungi isolated from atypical skin blemishes on potatoes in South Africa and Zimbabwe. Potato Res 60:119-144 